\title{
The Potential of Biodegradable Formulation from Petroleum Waste to Control the Powdery Mildew of Cucumber Singly or in Combination with (Difenoconazole + Azoxystrobin) \\ Abou Tabl, A. H. ${ }^{1}$; E. S. Sallam ${ }^{2}$ and Rawhia T. Abdulkader ${ }^{1}$ \\ ${ }^{1}$ Plant Pathology Department, Faculty of Agriculture, Mansoura University, El-Mansoura, Egypt \\ ${ }^{2}$ Soil, Water and Environment Research Institute (SWERI), Agricultural Research Centre (ARC), Egypt \\ ayman@mans.edu.eg
}

\section{ABSTRACT}

A biodegradable formulation from petroleum waste in comparison with the systemic fungicides difenoconazole + azoxystrobin combination at concentrations of 250 and $325(\mu \mathrm{g} / \mathrm{ml})$, respectively was applied as a foliar spray for the control of powdery mildew of cucumber caused by Sphaerotheca fuliginea. Plants were grown under the greenhouse conditions and two successive sprayins were carried out. The frist one was applied on 39-day-old plants and the second on the plants of 46days old. The results illustrated that the biodegreable waste has a potential to control the disease and was more effective in controlling the disease than the selected systemic fungicids. The results highlight the potential of this biodegradable formulation as a promising and economic method for controlling powdery mildew on cucumber. Also, it is less toxic on the plants than the used fungicides, while the plant constituents of phenols and chlorophyll were increased which are a clue for increasing the immune system of the treated plants. This biodegradable formulation from petroleum waste may be useful for controlling other diseases of cucumber or other crops.

Keywords: Difenoconazol, azoxystrobin, powdery mildew, cucumber, control, Sphaerotheca fuliginea, biodegradable petroleum waste, Pseudomanas fluorescens, Phanerochaete chrysosporium, hydrocarbon oxidizers, phloroglucinol, phenazine, benzoquinoline.

\section{INTRODUCTION}

Romero et al. (2004) reported that the characteristic visual symptoms of the powdery mildew on cucumber leaves is the development of a whitish, talcum-like powdery growth on both surfaces, petioles and stems. Infected leaves usually die prematurely (Zitter et al., 1996). The reduction in fruit quality is obvious while the crop yield is significantly reduced.

Stereoscopic microscope identification showed that the isolated fungi are, Golovinomyces cichoracearum or Podosphaera fusca (syn. Sphaerotheca fusca), (Braun et al., 2002).

Dai 1979, Tang et al., 2003 and Huang, 1999) reported that the fungul spores of these fungi are seedborne and the relative humidity take part in spreading the spores. They also aded that the incubation period for the spores to germinate and infect leaves is nearly $24 \mathrm{~h}$. Seven days later the disease clearly develop and causes a reduction in plant vigor started on seedling while the mature plants produce low quality fruits and decreased yield.

Biodegradation is a natural processes by microbes, which break down petroleum hydrocarbons and change them to other substances (Bragg et al., 1994). Pseudomonas fluorescens is one of the bacteria capable to degrade the petroleum waste in a process called Hydrocarbon oxidizers while the bacteria is known as Hydrocarbon oxidizers (Atlas, 1981).

Phanerochaete chrysosporium has also the ability to break down this wastes and remove $75-80 \%$ of all the total petroleum hydrocarbon in the polluted soil (Yateem et al., 1998).

\section{MATERIALS AND METHODS}

The present investigations was conducted during the year 2016. The treatments were designed and seeds were grown at the greenhouses of Plant Pathology Department, and Seed \& Tissue Pathology Lab (SEPA),
Central Laboratory, Faculty of Agriculture, Mansoura University, Egypt, located on campus.

\section{Source of the pathogen}

Sphaerotheca fuliginea fungus was isolated from the infected plants grown in the privet fields of cucumber at Dakahlia governerate. Samples of infected leaves were collected and deliverd to the fungal identification lab of the Institute of Plant Pathology, the Agriculture Research center, Giza, Egypt.

Multiplication and maintenance of cucurbit powdery mildew isolates

Subcultures of powdery mildew were incubated for 7 days in enclosed containers at $22 \pm 3^{\circ} \mathrm{C}$ under ambient lighting, before being transferred to fresh and healthy tissues or used in the bioassays. When sporulation was abundant, conidia were transferred to a new leaves to obtain ample quantity of inoculum to be used in the bioassays of the componants.

Pathogenicity test

The powdery mildew fungus (Sphaerotheca fuliginea)was maintained on the top leaves of cucumber plants followed by several successive transfer on new growing plants. Conidia were gently brushed and collected in a small quantity in distilled water containing two drops of Tween 20 and counted with the aid of a hemocytometer to give a suspension of $3 \times 10^{4}$ conidia $\mathrm{ml}^{-1}$. For inoculation, the upper surface of the leaves of the plants under investigation was uniformly sprayed with a conidial suspension delivered by a hand sprayer then covered with polyethylene bags and kept at $20^{\circ} \mathrm{C}$ for $20-24 \mathrm{~h}$ in dark. Five replicates were used in this treatment. Plants were then transferred back to the greenhouse benchs while the temperature was fluctuated between $20-32^{\circ} \mathrm{C}$ with days length of nearly $14 \mathrm{~h}$. Plants watered when necessary. The number of powdery mildew colonies produced on each leaf was recorded on the plants 10 days after the inoculation.

In another experiment, the desingend formulation from biodegradable petroleum wast was applied on the fungal inculated leaves 10 days after the inculation. The 
effect of the formulated degradable wast were recorded after 60 days as described by (Reuveni et al., 1996).

Disease assessment

Disease incidence

Percentage of disease incidence was recorded as recorded by the following equation:

$\%$ Powdery mildew
incidence $=$$\quad$\begin{tabular}{c}
$\begin{array}{c}\text { No. of powdery mildew symptoms } \\
\text { bearing plants }\end{array}$ \\
\cline { 2 - 2 }
\end{tabular}

Disease severity

Powdery mildew severity was assessed following standard severity scale: 0 (No disease symptom), 1 (1-25\% leaf area infected), 2 (26-50\% leaf areas infected), 3 (51$75 \%$ leaf areas infected), and $4(76-100 \%$ leaf areas infected (Cohen et al., (2004). The percentage of disease severity was recorded by the following equation:

$$
\begin{aligned}
& \begin{array}{c}
\text { Powdery mildew } \\
\text { severity }=
\end{array} \frac{\text { Sum of individual ratings }}{\text { Total no. of rating } x \text { maximum }} \times 100 \\
& \text { severity }=\text { disease grade }
\end{aligned}
$$

\section{Source of fungicides}

The chemicals viz., azoxystrobin $20 \mathrm{SC}$ and difenoconazol 12.5 SC were obtained from Syngenta Pvt. Ltd., Egypt.

Biodegradation of petroleum wastes (lubricating oil)

Two biodegradable isolates for petroleum wastes were used in this study. First is white rot fungi Phanerochaete chrysosporium and the second is bacteria Pseudomonas fluorescens NRRL 340. Both isolates were kindly obtained from Dr. Essam Eldin Sallam Ibrahim Sallam, Soil, Water and Environment Research Institute (SWERI), Agricultural Research Centre (ARC), Egypt.

A 10 Erlenmeyer flasks $(500 \mathrm{ml})$ were prepared with $90 \mathrm{ml}$ lubricant (spent car oil, petroleum waste) $\mathrm{pH}$ 6.8 in each one and sterilized at $121^{\circ} \mathrm{C}$ for $20 \mathrm{~min}$. All flasks were inoculated with $2 \mathrm{ml}$ of Phanerochaete chrysosporium $\left(1 \times 10^{5} \mathrm{ml}^{-1}\right), 6 \mathrm{ml}$ of peptone $1 \%$ as a carbon source. Flasks were incubated at $35 \pm 2^{\circ} \mathrm{C}$ in dark with shaking at 200rpm. After 10 days, two $\mathrm{ml}$ of Pseudomonas fluorescens NRRL $340\left(1 \times 10^{9} \mathrm{ml}^{-1}\right)$ were added, then incubated at $25 \pm 2^{\circ} \mathrm{C}$ in dark with shaking $200 \mathrm{rpm}$ for 3 days. After fermentation, $20 \mathrm{ml} 0.01 \mathrm{M}$ phosphate buffer $\mathrm{pH} 7.0$ were added and flasks were shacked for $20 \mathrm{~min}$. The biodegradable lubricant was filtrated through two layers of sterile cheesecloth and Whatman No.1 filter papers. The supernatant was kept under $4^{\circ} \mathrm{C}$ for further study.

High performance liquid chromatography (HPLC)

An HPLC system (Agilent Technologies, model 1050, Waldbronn, Germany)combined with quaternary pump, auto-sampler, diode array detector (HP-1050), fluorescence detector (HP-1046A), and data analysis software, was used. UV detection (214 nm)plus fluorescence detection $\lambda$ ex $260 \mathrm{~nm}$ )was applied.

Mass spectrometry (MS)

The Electron Impact Mass Spectra (EI-MS) had a delay of $3 \mathrm{~min}$. to avoid the solvent plead and then scanned from $\mathrm{m} / \mathrm{z} 50$ to $\mathrm{m} / \mathrm{z} 300$. Ionization energy was set at 70 $\mathrm{eV}$. The compounds were identified using Wiley and Nist 5.0 mass spectral database.

Statistical analysis

A one-way analysis of variance was conducted to analyze the data, by completely randomized design (CRD). Data collected from all experiments were statistically analyzed using the Statistical Analysis System package (SAS institute, Cary, NC, USA). Differences between treatments were determined using Fisher's least significant difference (LSD) test by Duncan's multiple range test (Duncun, 1955). All comparisons were performed at $\mathrm{P} \leq$ 0.05 .

\section{RESULTS}

\section{Pathogenicity test}

Three Sphaerotheca fuliginea isolates were tested for their pathogenicity, under greenhouse conditions, using susceptible cucumber plants Super Dalila F1 Hybrid, Data presented in Table (1)show that, the disease incidence caused by gamsa isolate was significantly higher than that of belqusa and badway isolates (100, 76.85 and $62.43 \%$, respectively). No significant difference between both isolates with regard to their disease severity was shown.

Table 1. Pathogenicity test of three Sphaerotheca fuliginea isolates (gamsa, belquas \& badway)on cucumber plants, 35 days old, under controlled greenhouse conditions.

\begin{tabular}{lcc}
\hline Treatment & $\begin{array}{c}\text { Disease } \\
\text { Incidence (\%) }\end{array}$ & $\begin{array}{c}\text { Disease } \\
\text { Severity (\%) }\end{array}$ \\
\hline Gamsa isolate & $100.00 \mathrm{a}^{\mathrm{c}}$ & $62.31 \mathrm{a}$ \\
Belquas isolate & $76.85 \mathrm{~b}$ & $46.26 \mathrm{~b}$ \\
Badway isolate & $62.43 \mathrm{c}$ & $42.83 \mathrm{~b}$ \\
Not inoculated (no fungus) & $0.00 \mathrm{c}$ & $0.00 \mathrm{~d}$
\end{tabular}

a \% Powdery mildew Incidence $=($ No. of Powdery Mildew Symptoms bearing plans/Total no. of Plants) x 100

b $\%$ Powdery mildew Severity $=$ [Sum of Individual Ratings/ (Total No. of Rating x Maximum Disease Grade)] x 100.

c Values within a column followed by the same letter are not significantly different according to Duncun's multiple range test $(P=0.05)$.

Two biodegradable isolates for petroleum wastes were used in this study, Phanerochaete chrysosporium and Pseudomonas fluorescens NRRL 340. After fermentation conditions in 13 days, the active ingredients in final supernatant were identified by the aid of HPLC technique, which showed the presence of three compounds namely: phloroglucinol, phenazine, and benzoquinoline. These compounds were characterized by comparing their mass spectra with those obtained by the NIST and WILEY libraries. The obtained results were tabulated in Table (2).

Table 2. Chemical composition of biodegradable

\begin{tabular}{|c|c|c|c|c|c|}
\hline No. & RT & Compounds & $\begin{array}{c}\text { Molecular } \\
\text { formula }\end{array}$ & $\begin{array}{c}\text { Molecular } \\
\text { weight }\end{array}$ & $\begin{array}{c}\text { Peak area } \\
(\%)\end{array}$ \\
\hline 1 & 1.325 & Phloroglucinol & $\mathrm{C}_{6} \mathrm{H}_{6} \mathrm{O}_{3}$ & 126.1 & 8.7955 \\
\hline 2 & 1.383 & Phenazine & $\mathrm{C}_{12} \mathrm{H}_{8} \mathrm{~N}_{2} \mathrm{O}$ & 180.2 & 11.2279 \\
\hline 3 & 1.464 & Benzoquinoline & $\mathrm{C}_{13} \mathrm{H}_{9} \mathrm{~N}$ & 179.2 & 9.023 \\
\hline
\end{tabular}
petroleum wastes (lubricating oil).

Data presented in Table (3)show that, disease incidence on infected plants by isolate sphaerotheca fuliginea in the control treatment increased by $41.75 \%$ on the plants of 60 days old. Also the combination of azoxystrobin and difenoconazol recorded $17.64 \%$ reduction in disease incidence on the plants of 60 days, while the disease incidence for biodegradable lubricant at a concentration of $400 \mu \mathrm{g} / \mathrm{ml}$ decreased the disease incidence down to $14.90 \%$. 
Table 3. Effect of biodegradable formulation, and premix of azoxystrobin and difenconazol concentrations as treatments on disease incidence and disease severity of cucumber plants on 60 days old inoculated with Sphaerotheca fuliginea.

\begin{tabular}{lccc}
\hline Treatment & $\begin{array}{c}\text { Conc. } \\
(\boldsymbol{\mu g} / \mathbf{m l})\end{array}$ & $\begin{array}{c}\text { Disease } \\
\text { Incidence }(\%)^{\mathbf{a}}\end{array}$ & $\begin{array}{c}\text { Disease } \\
\text { Severity }(\mathbf{\%})^{\mathbf{b}}\end{array}$ \\
\hline $\begin{array}{l}\text { Control (check) } \\
\text { Azoxystrobin }+\end{array}$ & 0 & $41.75 \mathrm{a}^{\mathrm{c}}$ & $30.44 \mathrm{~b}$ \\
Difenoconazol & 325 & $17.64 \mathrm{e}$ & $28.67 \mathrm{c}$ \\
\hline Biodegradable & 300 & $18.28 \mathrm{~d}$ & $20.04 \mathrm{e}$ \\
lubricant & 350 & $17.16 \mathrm{f}$ & $18.81 \mathrm{f}$ \\
\hline Not inoculated (no fungus) & $38.69 \mathrm{~b}$ & $27.66 \mathrm{~d}$ \\
\hline
\end{tabular}

${ }^{a} \%$ Powdery mildew Incidence $=($ No. of Powdery Mildew Symptoms bearing plans/Total no. of Plants) x 100

b\% Powdery mildew Severity = [Sum of Individual Ratings/ (Total No. of Rating x Maximum Disease Grade)] x 100.

c Values within a column followed by the same letter are not significantly different according to Duncun's multiple range test $(P=0.05)$.

The disease severity on the untreated plants showed $30.44 \%$ of on the 60 days old plants, while treatment with biodegradable lubricant at $400 \mu \mathrm{g} / \mathrm{ml}$ reduced disease severity down to $11.72 \%$ on the 60 days old plants. The disease severity of the combination of azoxystrobin + difenoconazol recorded $28.67 \%$.

Data presented in Table (4)recorded the total chlorophyll at a rate of $1.72 \mathrm{mg} / \mathrm{g}$ in the treatment in which combination of azoxystrobin $20 \%+$ difenoconazol $12.5 \%$ was applied on 60 days old plants infested with $S$. fuliginea. The check presented 1.14 only. On the other hand, there were significant differences in total phenol content between the treatment and the control plants which show 36.40 catechol $/ 100 \mathrm{~g}$ fresh weight)in the check, while the treatment of azoxystrobin $20 \%+$ difenoconazol $12.5 \%$ recorded 55.03 ( $\mathrm{mg}$ catechol/100 $\mathrm{g}$ fresh weight), respectively.

The treatment in which the the biodegradable waste was applied showed $15 \%$ reduation in the disease incidence. The total chlorophyll recorded $2.18 \mathrm{mg} / \mathrm{g}$ compair to 1.1 in the check. In case of the total phenol it recorded 69.70 (mg catechol/100 $\mathrm{g}$ fresh weight), while it was 36.4 in the check.

Table 4. Effect of combination of premix of azoxystrobin + difenoconazol as well as the biodegradable formulation on the contents of Chlorophyll A, B (Chl. A, Chl. B), total chlorophyll (T. Chl.), carotenoids (Carot.), and total phenol (T. Phenol) in leaves of 60 days old plants inoculated with Sphaerotheca fuliginea.

\begin{tabular}{lcccccc}
\hline Treatment & $\begin{array}{c}\text { Conc. } \\
(\boldsymbol{\mu g} / \mathbf{m l})\end{array}$ & $\begin{array}{c}\text { Chl. A } \\
(\mathbf{m g} / \mathbf{g})\end{array}$ & $\begin{array}{c}\text { Chl. B } \\
(\mathbf{m g} / \mathbf{g})\end{array}$ & $\begin{array}{c}\text { T.Chl. } \\
(\mathbf{m g} / \mathbf{g})\end{array}$ & $\begin{array}{c}\text { Carot. } \\
(\mathbf{m g} / \mathbf{g})\end{array}$ & $\begin{array}{c}\text { T. Phenol (mg catechol } \\
/ \mathbf{1 0 0} \text { g fresh weight) }\end{array}$ \\
\hline Control (check) & 0 & $0.664 \mathrm{f}^{\mathrm{a}}$ & $0.475 \mathrm{~d}$ & $1.139 \mathrm{e}$ & $0.066 \mathrm{~d}$ & $36.396 \mathrm{~d}$ \\
Azoxystrobin + Difenoconazol & 325 & $1.004 \mathrm{~b}$ & $0.718 \mathrm{~b}$ & $1.722 \mathrm{~b}$ & $0.1 \mathrm{~b}$ & $55.03 \mathrm{~b}$ \\
\hline \multirow{2}{*}{ Biodegradable lubricant } & 300 & $0.825 \mathrm{de}$ & $0.589 \mathrm{~cd}$ & $1.415 \mathrm{~cd}$ & $0.082 \mathrm{c}$ & $45.21 \mathrm{c}$ \\
& 350 & $0.875 \mathrm{~cd}$ & $0.625 \mathrm{bc}$ & $1.501 \mathrm{~d}$ & $0.087 \mathrm{bc}$ & $47.95 \mathrm{bc}$ \\
\hline Not inoculated (no fungus) & 400 & $1.272 \mathrm{a}$ & $0.909 \mathrm{a}$ & $2.181 \mathrm{a}$ & $0.126 \mathrm{a}$ & $69.69 \mathrm{a}$ \\
\hline
\end{tabular}

${ }^{a}$ Values within a column followed by the same letter (s) are not significantly different according to Duncun's multiple range test $(P=0.05)$.

\section{DISCUSSION}

Powdery mildew is one of the most economically important disease attacking cucumber world-wide. The disease is caused by the air-bone fungus Sphaerotheca fuliginea. The awareness of this disease was increased as its impact on the yield is drastic and cause higher loss in the fruit yield of cucumber; one of the important vegetable crop and mandatory in our daily dites. Chemical control of disease especially in the vegetables of short life span including cucumber has hazard effect on the human health when accumulated in the edable parts of the crop in return to the improper and carelessness application. Moreover, their direct effect on the labors health during the application process especially in the third world while safty regulations are never followed. Care and exercise for the proper time of appliying the toxic chemicals (fungicids)on the growing plants is also never happened. So far, the present investigation was carried out to evaluate the effect of the biodegradabel petroleum wast as a less toxic products for controlling the powdery mildew of cucumber since the intensive spray of fungicids are commonly used in greenhouses. This study was carried out during two successive growing season (2016)and the research was designed to use the soil-borne bacterium Pseudomanas fluorescens to biodegrade the petroleum waste which nearly take 7 days. The research data when statistically analized has proved the efficacy of the degradable waste by Pseudomanas fluorescens for controling the disease as it give $61.49 \%$ reduction in the disease incidence in compar to $5.8 \%$ when the compination of azoxystrobin + difenoconazol was applied while the check plants showed $100 \%$ infection. The presented results clearly demonastrate the possible use of the formulation gained from the biodegradation of petroleum waste as an alternative and safe method for controling the powdery mildew occures on cucumber and other edable vegetable crops. While the chemical constituents of chlorophyll and total phenols are taken as indicator and clue for increasing the immune system of the plants and produce healthy edible parts of the crop. Unless the proper timing of the systemic fungicids used for controling the diseases their residues in the plants and fruits is commonly found. From an economic stand point, the biodegrdable formulation produced from petroleum wast has proved to be a promising for controling this disease which has a lower risk on human and their diet and also to the environment as well. In this respect, it is recommended to expand applying this formulation on other vegetables and field crops not 
only under greenhouse condition but also on a large scale in the open fields.

\section{REFERENCES}

Atlas, R. M. (1981). Microbial degradation of petroleum hydrocarbons; an environmental perspective. Microbiol. Rev., 45: 180-209.

Bragg, J.R. ; R.C. Prince; E.J. Harner and R.M. Atlas (1994). Effectiveness of bioremediation for Exxon Valdez oil spill. Nature, 368: 413 -418.

Braun U., Cook T.A., Inman A.J. and Shin H.D., 2002. The taxonomy of the powdery mildew fungi. In: Bélanger RR, Bushnell WR, Dik AJ, Carver TLW (eds) The powdery mildews. A comprehensive treatise. APS Press, St Paul, Minn., pp 13-55.

Cohen R., Burger Y., Katzir N., 2004. Monitoring physiological races of Podosphaera xantii (syn. Sphaerotheca fuliginea), the causal agent of powdery mildew in cucurbits: Factors affecting race identification and the importance for research and commerce. Phytoparasitica 32: 174-183.

Dai, F.L., 1979. Comprehensive Collection of Fungus of China. Science Publishing House, Beijing, pp. 134-136, 318-321.
D. Romero A.; Pérez-García M. E.; Rivera F. M. and Cazorla A. de Vicente, 2004. Isolation and evaluation of antagonistic bacteria towards the cucurbit powdery mildew fungus Podosphaera fusca. Appl Microbiol Biotechnol, 64: 263-269

Duncun, D. B., 1955. Multi ple ranges and multiple F test. Biometrics, 11:1-42.

Huang, Z.S., 1999. Control technology of major pests of vegetables in sunlight greenhouse: generation and control of Sphaerotheca fuliginea. J. Veg. $12,23$.

Reuveni M.; V. Agapov and F.L. Reuveni, 1996. Controlling powdery mildew caused by Sphaerotheca fuliginea in cucumber by foliar sprays of phosphate and potassium salts .crop protection vol. 15(1): 49-53.

Tang, R., Zhang, X.H., Zhao, J.Y., 2003. Research development of cucumber powdery mildew. J. Acta Agric. North China Sin. 18 (Suppl.), 68-70.

Yateem, A.; Balba, M.T.; AI-Awadhi N. and EINawawy, A.S. (1998). Fungi and their role in remediating oil-contaminated soil. Environment International, Vol. 24, No. 1/2, pp. 181-187.

Zitter T.A., Hopkins D.L. and Thomas C.E., 1996. Compendium of cucurbits diseases. APS Press, St Paul, Minn.

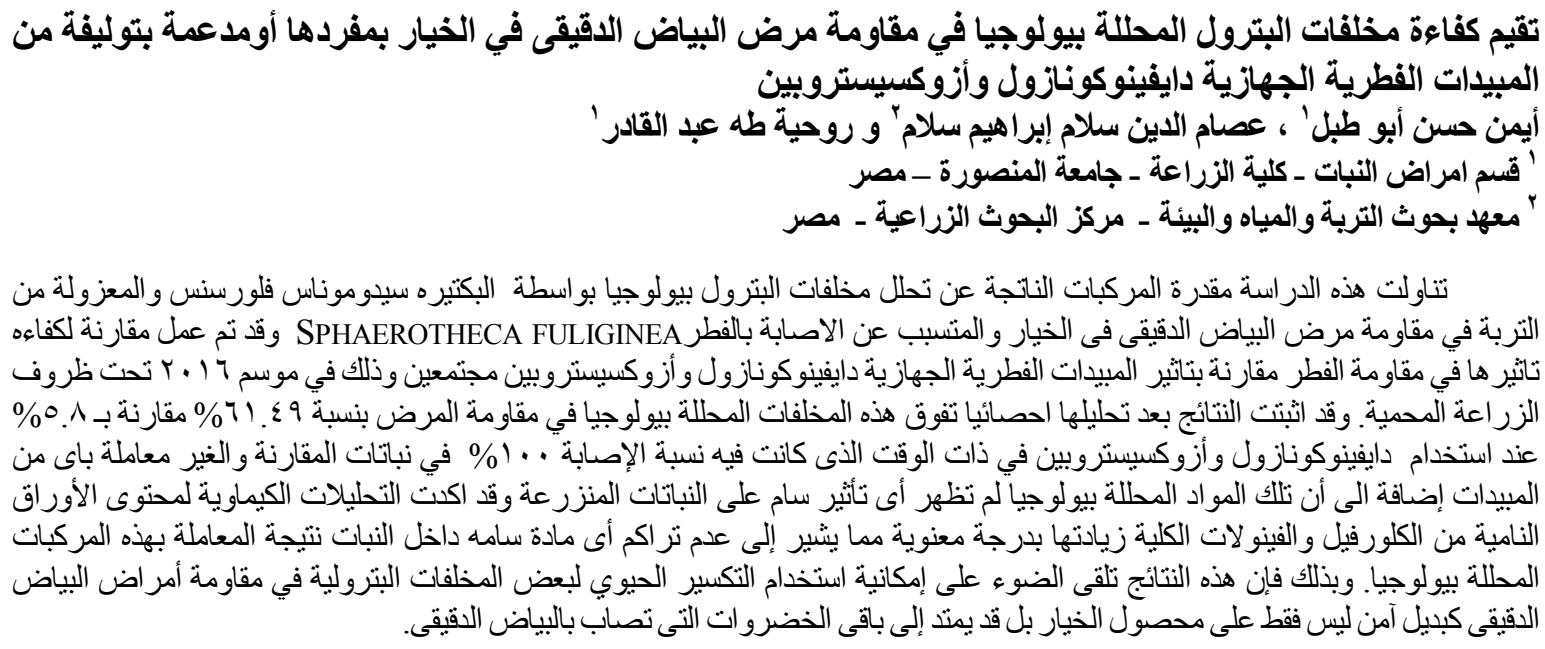

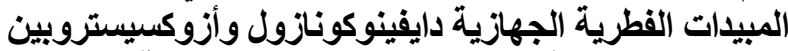

